\title{
NOTE
}

\section{Effect of strain origin on siderophore production in Vibrio harveyi isolates}

\author{
Leigh Owens $^{1, *}$, Dawn A. Austin ${ }^{2}$, Brian Austin ${ }^{2}$ \\ ${ }^{1}$ Department of Biomedical and Tropical Veterinary Sciences, PO James Cook University of North Queensland, Townsville, \\ Queensland, Australia 4811 \\ ${ }^{2}$ Department of Biological Sciences, Heriot-Watt University, Riccarton, Edinburgh EH14 4AS, Scotland, UK
}

\begin{abstract}
A total of 92 isolates of Vibrio harveyi (as identified by ribotyping) were tested for siderophore activity on a modified chrome azurol sulphate agar. Whilst 4 isolates failed to grow, of the remaining 88 strains, $78.4 \%$ were positive for the production of siderophores. There was no correlation between siderophore production and length of time since isolation. There were significant differences between the host groups from which the bacteria were isolated $(F=3.23, \mathrm{df}=$ $3,85 ; \mathrm{p}<0.05)$. The colony halos produced by environmental isolates (halo to colony ratio $=2.7$ ) and fish isolates (halo ratio $=2.4$ ) were significantly larger than the halos from invertebrate isolates (halo ratio $=1.6$ ). Pathogenicity in an Atlantic salmon bioassay was barely significantly related to siderophore production $(t=-1.87, \mathrm{df}=64 ; \mathrm{p}<0.1)$. The maximal non-inhibitory levels of $2,2^{\prime}$-dipyridyl showed no association with siderophores $(t=-1.65, \mathrm{df}=30, \mathrm{p}>0.05)$ nor with pathogenicity $(t=0.16, \mathrm{df}=87 \mathrm{p}>0.05)$. Siderophores must be considered a virulence factor in piscine infecting $V$. harveyi but not in strains infecting invertebrates.
\end{abstract}

KEY WORDS: Vibrio harveyi Siderophore - Virulence

Vibrio harveyi is a major pathogen of aquatic animals including fish (Kraxenberger-Beatty et al. 1990, Anderson \& Norton 1991) crustacea (Lavilla-Pitogo et al. 1992, Owens et al. 1992) and bivalves (Pass et al. 1987). It is the main causative agent of luminous vibriosis which plagues tropical prawn hatcheries worldwide and it is considered the most important disease in the Philippines (Lavilla-Pitogo et al, 1990). Despite this, the mechanisms of virulence of this bacterium are unknown. Working with 16 strains including 2 highly virulent strains that killed prawn protozoea at $10^{2}$ and $10^{5}$ cells $\mathrm{ml}^{-1}$, Harris (1993) showed that only 1 strain (and neither of the 2 strains above) had a very small plasmid, and so plasmid-borne pathogenicity was unlikely.

•E-mail: leigh.owens@jcu.edu.au
Siderophores are bacterially secreted molecules with high affinity for iron that scavenge iron from the bacterial cells environment for growth, particularly for replication of the cytochrome systems. Siderophore production is often accompanied by the production of iron repressible outer membrane proteins (IROMP) which act as receptors for the iron-siderophore complex (Crosa 1989). These systems have been found to be major determinates of virulence in Vibrio anguillarum (Pybus et al. 1994), Vibrio cholerae non-O1 (Amaro et al. 1990) and Aeromonas salmonicida (Hirst \& Ellis 1994). Harris (1993) failed to demonstrate the importance of siderophores to virulence of $V$. harveyi but his study only included 16 strains. The present study was an attempt to expand on the limited sample size of Harris's study and determine if indeed there might be a role for siderophores as determinates of virulence in V. harveyi.

Material and methods. Bacterial strains: A total of 93 Vibrio harveyi strains identified by ribotyping were taken out of $-70^{\circ} \mathrm{C}$ storage and were grown overnight at $22^{\circ} \mathrm{C}$ in Oxoid tryptone soya broth supplemented with $1 \%$ sodium chloride $(\mathrm{w} / \mathrm{v})$. These broth cultures were streaked onto Oxoid tryptone soya agar plates supplemented with $1 \%$ sodium chloride $(\mathrm{w} / \mathrm{v})$ (NTSA) and checked for purity by colony morphology after overnight growth at $22^{\circ} \mathrm{C}$.

Siderophore production: Siderophore production was measured by a modified Chrome Azurol Sulphate (mCAS) agar method of Schwyn \& Neilands (1987). The MM9 salts, casamino acids and carbon source were all replaced by the NTSA nutrients. This agar had available iron other than that presented in the CAS-complex. To make iron-limiting conditions, $0.1 \mathrm{mM} \mathrm{2,2}$-dipyridyl was added to the agar before autoclaving. The final mCAS plates were a greyish 
blue rather than the normal sky blue of CAS. All ingredients were purchased from Sigma Chemical Company.

Eight individual colonies were transferred from the NTSA plates with sterile toothpicks to mCAS. The plates were grown at $22^{\circ} \mathrm{C}$ and read at 24 and $48 \mathrm{~h}$ to ensure the Vibrio harveyi had reached stationary phase (Schwyn \& Neilands 1987). Only 1 strain, 570, differed between the $24 \mathrm{~h}$ (nonproducer) and $48 \mathrm{~h}$ (producer) readings. The size of the zone of clearance (orange halo) had to be 1.3 times the size of the colony to be considered a siderophore producer (Amaro et al. 1990) and the mean values of the 8 colonies was used for this calculation. A Vibrio anguillarum strain (44) was used on all batches of plates as a known positive siderophore producer (Austin \& Austin unpubl. data).

Normal NTSA was supplemented with various amounts of 2,2'dipyridyl before autoclaving to make up final concentrations of 20,50,100,200,400 and $1000 \mu \mathrm{M}$. All strains were checked for their ability to grow at 20 and $50 \mu \mathrm{M}$. A random selection of 30 strains was tested for growth at higher levels of iron binding.

Fish pathogenicity experiments: Vibrio harveyi were tested for pathogenicity in Atlantic salmon Salmo salar (Austin \& Austin unpubl. data) and the conclusions were used herein to determine if there was any association between siderophore production and pathogenicity. Briefly the protocol was as follows. Ten fish $(15$ to $20 \mathrm{~g})$ were intraperitoneally injected with a 0.1 $\mathrm{ml}$ inoculum ranging from $10^{4}$ to $10^{6}$ washed bacterial cells $\mathrm{ml}^{-1}$ The fish were monitored for $14 \mathrm{~d}$ in aerated, static water at $15^{\circ} \mathrm{C}$. Dead and moribund fish were subjected to standard bacteriological examination (Austin \& Austin 1989) and, if the mortalities were repeated in a subsequent similar experiment, that categorised the $V$. harveyi strain as pathogenic.

Statistics: Standard statistical tests such as $t$-tests, ANOVA, least-significant difference analysis, regression analysis, and chi-squared tests were performed using Statistix $4.0^{\mathrm{TM}}$ (Analytical Software, St. Paul, MN, USA)

Results. Four isolates failed to grow on the mCAS, 3 isolated from invertebrates and 1 isolated from fish. Of those that grew, 19 of 88 (21.6\%) strains were negative for the production of siderophores. Of the negative strains, 9, 6, 2 and 2 respectively were isolated from fish, invertebrates, environment and unknown. Using the chi-squared test, none of the groups were more negative for the production of siderophores than expected by their frequencies in the tested population.

There was no correlation between the year of isolation and siderophore activity $(t=0.61, \mathrm{df}=61 ; \mathrm{p}>0.05)$. This meant that siderophore activity had not been lost or gained by repeated subculturing and maintenance of older isolates. Therefore, conclusions reached re- garding siderophore activity should be valid and represent the real population of Vibrio harveyi, and do not reflect differences in culturing conditions.

When testing to see if there was any significance difference in siderophore activity between the hosts from which the bacteria were isolated, the variances between the groups were not homogenous $\left(\chi^{2}=9.3\right.$, $\mathrm{df}=2 ; \mathrm{p}<0.05)$. Therefore, a square root transformation was applied and the variances became homogenous $\left(\chi^{2}=0.5\right.$, $\left.\mathrm{df}=2 ; \mathrm{p}>0.05\right)$. This procedure was followed whenever groups had non-homogenous variances. A 1-way ANOVA showed that there were significant differences between the host groups from which the bacteria was isolated ( $F=3.23, \mathrm{df}=3,85$; $\mathrm{p}<$ 0.05). Least Significant Difference analysis (LSD) showed that the halos from environmental isolates (ratio of the halo to the colony size $=2.7$ ) and fish isolates (halo ratio $=2.4$ ) were similar. Halos of the bacteria from both these host groups were significantly larger (via LSD) than the halo from invertebrate isolates (halo ratio $=1.6$ ).

Pathogenicity as measured in the fish bioassay was barely significantly related to siderophore production $(t=-1.87$, df $=64 ; p<0.1)$.

All strains could grow at 20 and $50 \mu \mathrm{M}$ concentrations of 2,2-dipyridyl. The maximal non-inhibitory levels of 2,2-dipyridyl showed no association with the levels of siderophore produced $(t=-1.65, \mathrm{df}=29 ; \mathrm{p}>$ $0.05)$ nor were they linked to pathogenicity $(t=0.16$, $\mathrm{df}=29 ; \mathrm{p}>0.05)$. The square-root transformation of the maximal non-inhibitory levels of 2, $2^{\prime}$-dipyridyl showed a limited significant difference between host groups $(t=2.73, \mathrm{df}=29 ; \mathrm{p}<0.1)$. Those strains isolated from fish were most resistant, followed by those from invertebrates, and those from the environment were least resistant.

Discussion. In Vibrio harveyi, siderophore activity was linked to the host group from which the bacterium was isolated, with invertebrate isolates having the lowest level of activity. Furthermore, siderophore activity appeared to be linked to pathogenicity in Atlantic salmon although a small doubt must remain. Therefore, siderophore systems should be considered a determinate of pathogenicity in vertebrates, much as in the same way siderophores in $V$. anguillarum are viewed (Pybus et al. 1994).

On the other hand, siderophores in Vibrio harveyi from invertebrates appear to be of lesser consequence for maintaining infections. Certainly, invertebrates do not seem to have the extensive iron-binding compounds such as lactoferrin, transferritin and haemoglobin as do vertebrates. The battle for iron between bacteria and invertebrates is not as intense as in vertebrates. The invertebrates seem not to have methods of sequestering iron away from the bacteria and, since 
Table 1. Vibrio harveyi. Characteristics of the strains tested for siderophore production. Pathogenicity was determined in an Atlantic salmon bioassay. A blank in the siderophore column indicates that the isolate did not grow, probably due to 2,2 dipyridyl toxicity. A blank in other columns indicates missing data

\begin{tabular}{|c|c|c|c|c|c|c|c|c|c|c|c|}
\hline Strai & in & $\begin{array}{l}\text { Path. to } \\
\text { Atl. sal.? }\end{array}$ & $\begin{array}{l}\text { Siderophore } \\
(\text { mean } \pm S D)\end{array}$ & Year & $\begin{array}{l}\text { Country of } \\
\text { origin }\end{array}$ & Stral & Isolated from & $\begin{array}{l}\text { Path. to } \\
\text { Atl sal.? }\end{array}$ & $\begin{array}{l}\text { Siderophore } \\
(\text { mean } \pm S D)\end{array}$ & $\begin{array}{c}\text { Year } \\
-\end{array}$ & $\begin{array}{c}\text { Country of } \\
\text { origin }\end{array}$ \\
\hline 22 & Dicentrarchus labrax & $x$ Yes & $3.1 \pm 0.38$ & 91 & Greece & 609 & Unknown & No & $5.2 \pm 0.53$ & 94 & \\
\hline 23 & Dicentrarchus labrax & $x$ Yes & $4.0 \pm 0.38$ & 91 & Greece & 618 & Penaeid & No & $1.6 \pm 0.42$ & 94 & Venezuela \\
\hline 24 & Sparus aurata & Yes & $3.2 \pm 0.38$ & 91 & Greece & 622 & Penaeid & No & $1.8 \pm 0.53$ & 94 & Venezuela \\
\hline 184 & Artemia & Yes & - & 90 & Spain & 628 & Paguara & No & $1.0 \pm 0.18$ & 94 & Venezuela \\
\hline 185 & Artemia & Yes & $1.4 \pm 0.18$ & 90 & Spain & 629 & Bivalve & No & $1.8 \pm 0.26$ & 94 & Venezuela \\
\hline 214 & Seawater & Yes & $2.4 \pm 0.46$ & 91 & Greece & 631 & Bivalve & No & $3.2 \pm 1.07$ & 94 & Venezuela \\
\hline 286 & Chromis plumbeus & No & $1.4 \pm 0.46$ & 82 & USA & 633 & Paguara & Yes & $3.0 \pm 0.74$ & - & Venezuela \\
\hline 295 & Talorchestra & No & - & - & USA & 641 & Shellfish & No & $2.8 \pm 0.50$ & - & Japan \\
\hline 326 & Eel & No & $1.5 \pm 0.27$ & 90 & Belgium & 642 & Shellfish & No & $0.1 \pm 0.18$ & - & Japan \\
\hline 336 & Shrimp & No & $1.9 \pm 0.37$ & 80 & Senegal & 643 & Chanos chanos & No & $1.6 \pm 0.46$ & - & Japan \\
\hline 337 & Fish & No & $0.9 \pm 0.18$ & 80 & Senegal & 644 & Chanos chanos & No & $1.8 \pm 0.70$ & - & Japan \\
\hline 341 & Seawater & No & $4.5 \pm 1.12$ & 81 & Senegal & 645 & Sea bass & No & $2.1 \pm 0.82$ & 93 & Tunesia \\
\hline 343 & Caspian seawater & No & $1.4 \pm 0.32$ & 81 & lran & 646 & Aquarium water & Yes & $3.0 \pm 1.31$ & 93 & Denmark \\
\hline $350^{*}$ & Unknown & Yes & $3.2 \pm 1.70$ & - & - & 647 & Sea bream & Yes & $5.2 \pm 1.64$ & 92 & Greece \\
\hline 351 & Unknown & Yes & $2.5 \pm 0.46$ & - & - & 648 & Shark & Yes & $4.2 \pm 1.00$ & 93 & Denmark \\
\hline 391 & Shrimp & Yes & $1.2 \pm 0.26$ & 90 & Thailand & 649 & Sea bream & Yes & $2.9 \pm 1.27$ & 93 & Malta \\
\hline 392 & Lates calcanifer & No & $1.8 \pm 0.26$ & - & Australia & 650 & Sea bass & No & $2.8 \pm 0.18$ & 93 & Greece \\
\hline 393 & Lates calcarifer & No & $2.9 \pm 0.27$ & - & Australia & 651 & Aquarium water & Yes & $3.4 \pm 0.83$ & 94 & Denmark \\
\hline 394 & Lates calcarifer & No & $0.7 \pm 0.71$ & - & Australia & 652 & Sea bass & Yes & $3.1 \pm 0.74$ & 93 & Italy \\
\hline 395 & Prawn & No & $2.6 \pm 0.26$ & - & India? & 653 & Sea bass & Yes & $3.2 \pm 1.43$ & 93 & Turkey \\
\hline 396 & Seawater & No & $1.1 \pm 0.38$ & - & Red Sea & 654 & Aquarium water & No & $4.7 \pm 0.18$ & 94 & Denmark \\
\hline 397 & Seawater & No & $1.1 \pm 0.35$ & - & Hawaii & 655 & Sea bass & No & $1.9 \pm 0.42$ & 89 & France \\
\hline 398 & Seawater & No & $2.0 \pm 0.35$ & - & Italy & 656 & Sea bass & No & $1.0 \pm 0.18$ & 90 & Greece \\
\hline 399 & Seawater & Yes & $2.2 \pm 0.23$ & - & Hawài? & 657 & Sea bass & No & $2.7 \pm 0.38$ & 90 & France \\
\hline 400 & Unknown & No & $0.7 \pm 0.29$ & - & - & 658 & Sea bream & Yes & $3.1 \pm 0.56$ & 90 & France \\
\hline 401 & Seawater & No & $1.4 \pm 0.53$ & - & USA & 659 & Sea bass & Yes & $1.9 \pm 0.18$ & 90 & Tunesia \\
\hline 402 & Seawater & No & $6.6 \pm 0.96$ & - & - & 660 & Sea bass & No & $3.9 \pm 0.83$ & 90 & Greece \\
\hline 403 & Penaeus monodon & No & $0.9 \pm 0.23$ & - & Thasland & 661 & Sea bass & Yes & $1.0 \pm 0.23$ & 92 & Tunesia \\
\hline 404 & Penaeus monodon & No & $1.8 \pm 0.42$ & - & Thailand & 665 & Aquarium water & No & $2.1 \pm 0.91$ & 93 & Denmark \\
\hline 405 & Penaeus monodon & No & $1.1 \pm 0.18$ & - & Thailand & 666 & Aquarium water & No & $1.3 \pm 0.25$ & 93 & Denmark \\
\hline 406 & Penaeus monodon & No & $0.9 \pm 0.35$ & - & Thailand & 667 & Aquarium water & No & $2.1 \pm 0.85$ & 94 & Denmark \\
\hline 408 & Penaeus monodon & No & $1.7 \pm 0.18$ & - & Thailand & 696 & Oyster & No & $1.7 \pm 0.26$ & 89 & Spain \\
\hline 409 & Penaeus monodon & No & - & - & Thailand & 697 & Oyster & No & $1.3 \pm 0.18$ & 89 & Spain \\
\hline 411 & Fish & No & $1.0 \pm 0.20$ & 86 & Sth Africa & 771 & Blue tang & No & $4.9 \pm 0.98$ & - & Australia \\
\hline 413 & Seawater & No & $4.0 \pm 0.89$ & 88 & France & 775 & Salmo salar & No & - & - & Australia \\
\hline 538 & Shrimp & No & $1.1 \pm 0.38$ & 92 & Thailand & 788 & Sparus aurata & No & $1.4 \pm 0.18$ & 88 & Spain \\
\hline 560 & Sea bass & No & $1.3 \pm 0.60$ & 86 & Spain & 789 & Sparus aurata & No & $2.6 \pm 0.98$ & 88 & Spain \\
\hline 561 & Sea bass & No & $3.2 \pm 0.79$ & 88 & Spain & 796 & Unknown & No & $1.0 \pm 0.14$ & - & Sri Lanka \\
\hline 568 & Scophthalmus & Yes & $2.1 \pm 0.58$ & 90 & Spain & 803 & Shrimp & No & $4.8 \pm 1.73$ & 92 & Thailand \\
\hline & maximus & & & & & 811 & Dicentrarchus labrax & No & $4.3 \pm 1.95$ & 86 & Spain \\
\hline 569 & Scophthalmus & No & $2.1 \pm 0.42$ & 90 & Spain & 812 & Dicentrarchus labrax & No & $6.3 \pm 1.69$ & 88 & Spain \\
\hline & maximus & & & & & 816 & Sediment & No & $2.8 \pm 0.90$ & 94 & Venezuela \\
\hline 570 & Sparus aurata & Yes & $1.1 \pm 0.26$ & 90 & Span & 818 & Unknown & No & $5.9 \pm 1.31$ & 80 & France \\
\hline 571 & Sea bass & Yes & $1.5 \pm 0.82$ & 90 & Spain & 819 & Fish & No & $1.0 \pm 0.24$ & 80 & Senegal \\
\hline 572 & Sea bream & Yes & $2.2 \pm 0.27$ & 90 & Spain & 822 & Shrimp & No & $1.7 \pm 0.26$ & 80 & Senegal \\
\hline 573 & Sea bass & Yes & $2.3 \pm 0.44$ & 90 & Spain & 853 & Salmo salar & No & $1.4 \pm 0.32$ & - & Tasmania \\
\hline 574 & Sea bass & Yes & $2.2 \pm 0.59$ & 91 & Spain & \multirow{3}{*}{\multicolumn{6}{|c|}{$\begin{array}{l}\text { "This strain was a swarmer and was assumed to be Vibrio algmolyti- } \\
\text { cus and therefore not used in any calculations }\end{array}$}} \\
\hline 584 & $\begin{array}{l}\text { Scophthalmus } \\
\text { maximus }\end{array}$ & No & $1.0 \pm 0.23$ & 93 & Spain & & & & & & \\
\hline 585 & Sparus aurata & No & $2.1 \pm 0.60$ & 91 & Spain & & & & & & \\
\hline
\end{tabular}

the bacteria are not so challenged, they do not maximise siderophore expression.

The seawater environment is renowned for the low bioavailability of certain elements. Iron is quickly oxidised to ferric salts and precipitates out, thus becoming biologically unavailable particularly at neutral or alkaline $\mathrm{pH}$. Therefore, it is not surprising that siderophore activity is high in environmental isolates. The fact that the environmental isolates of Vibrio harveyi tested here have siderophore activity equivalent to that of the vertebrate isolates tested here suggests that environmental isolates are preadapted for surviving in fish.

The lack of correlation between 2,2'-dipyridyl tolerance and siderophores was similar to the lack of association between siderophores and EDDA [ethylenediamine-dilo-hydroxyphenylacetic acid) (Amaro et al. 1990), which is another iron chelator similar to 2, 2'dipyridyl in action. This lack of correlation probably means there are other mechanisms for acquiring iron besides the siderophore system as in Aeromonas salmonicida (Hirst et al. 1994). The level of siderophore- 
negative strains of Vibrio harveyi (22\%) was higher than the level of siderophore-negative $V$. cholerae non-O1 (6.5\% of 156 strains) found by Amaro et al. (1990). This was probably due to using 2,2'-dipyridyl as an iron chelator in the normal nutrient agar for a bacterium and this method is probably not as sensitive as the original CAS agar.

The demonstration of a role for siderophores in the virulence of Vibrio harveyi, particularly in fish, suggests that further studies on IROMP, and maybe a characterisation of the type of siderophores, are warranted. IROMP in particular are good candidate antigens for vaccination (Hirst \& Ellis 1994), especially if whole cell preparations are unsuccessful.

Evidence is accumulating that Vibrio harveyi has 2 major biotypes. Pizzutto \& Hirst (1995) found 2 major DNA and protein profiles for Australian strains of $V$. harveyi. The major pathogenic strains of $V$. harveyi of prawns are sucrose-negative whilst the sucrose-positive strains are benign and even used as probiotics. The BIOLOG ${ }^{\mathrm{TM}}$ identification system based on utilisation of 95 carbon sources recognises 2 biotypes, and the production of siderophores tends to suggest 2 biotypes as well. Perhaps, there are 2 separate species now being classified under the a name of $V$. harveyi, and this may be a fruitful area of investigation.

Acknowledgements. The laboratory studies were supported financially by European Union Grant No AIR-CT92-0341. The senior author's Special Study Leave was supported by James Cook University of North Queensland.

\section{LITERATURE CITED}

Amaro C, Aznar R, Alcaide E, Lemos ML (1990) Iron-binding compounds and related outer membrane proteins in Vibrio cholerae non-O1 strains from aquatic environments Appl Environ Microbiol 56:2410-2416

Anderson IG, Norton JH (1991) Diseases of barramundi in aquaculture. Austasia Aquaculture 5:21-24

Austin B, Austın DA (1989) Methods for the microbiological

Responsible Subject Editor: D. W. Bruno, Aberdeen, Scotland, UK examination of fish and shellfish. Ellis Horwood, Chichester

Crosa JH (1989) Genetics and molecular biology of siderophore-mediated iron transport in bacteria. Microbiol Rev $53: 517-530$

Harris L (1993) An investigation into the virulence of strains of Vibrio harveyi pathogenic to larvae of the tiger prawn Penaeus monodon. Honours thesis, James Cook University of North Queensland, Townsville

Hirst ID, Ellis AE (1994) Iron-regulated outer membrane proteins of Aeromonas salmonicida are important protective antigens in Atlantic salmon against furunculosis. Fish Shellfish Immunol 4:29-45

Hirst ID, Hastings TS, Ellis AE (1994) Utilisation of haem compounds by Aeromonas salmonicida. J Fish Dis 17:365-373

Kraxenberger-Beatty T, McGarey DJ, Grier HJ, Lim DV (1990) Vibrio harveyi an opportunistic pathogen from the common snook Centropomus unidecimalis (Bloch) held in captivity. J Fish Dis 13:557-560

Lavilla-Pitogo CR, Albright LJ, Paner MG, Sunaz NA (1992) Studies on the source of luminescent Vibrio harveyi in Penaeus monodon hatcheries. In: Shariff $M$, Subasinghe RP, Arthur JR (eds) Diseases in Asian aquaculture I. Fish Health Section Asian Fisheries Society, Manila, p 157-164

Lavilla-Pitogo CR, Baticados MCL, Cruz-Lacierda ER, de la Pena LD (1990) Occurrence of luminous bacterial disease of Penaeus monodon larvae in the Philippines. Aquaculture 91:1-13

Owens L, Muir PR, Sutton D, Wingfield M (1992) The pathology of microbial diseases in tropical Australian crustacea. In: Shariff M, Subasinghe RP, Arthur JR (eds) Diseases in Asian aquaculture 1. Fish Health Section Asian Fisheries Society, Manila, p 165-172

Pass DA, Dybdahl R, Mannion MM (1987) Investigations into the causes of mortality of the pearl oyster Pinctada maxima (Jamson) in Western Australia. Aquaculture 65: $149-169$

Pizzutto M, Hirst RG (1995) Classification of isolates of Vibrio harveyi virulent to Penaeus monodon larvae by protein profile analysis and M13 DNA fingerprinting. Dis Aquat Org 21:61-68

Pybus V, Loutit MW, Lamont IL, Tagg JR (1994) Growth inhibition of the salmon pathogen Vibrio ordalii by a siderophore produced by Vibrio anguillarum strain VL4355. J Fish Dis 17:311-324

Schwyn B, Neilands JB (1987) Universal chemical assay for the detection and determination of siderophores. Analyt Biochem 160:47-56

Manuscript first received: April 2, 1996

Revised version accepted: July 4, 1996 